\title{
PROGRAMME OF SESSIONS
}

Monday, 19 June 2000

OPENING OF SYMPOSIUM:

\author{
Marshall Lind, Chancellor, University of Alaska Fairbanks \\ Robert A. Bindschadler, President, International Glaciological Society \\ Martin O. Jeffries, Chairman, Local Organizing Committee and Chief Editor
}

0830-1030 h

CHAIR: Manfred A. Lange

\section{SESSiOn 1: Polynyas: Antarctic}

S. S. Jacobs: Polynyas in the Southern Ocean

N. L. Bindoff, G. D. Williams and Ian Allison: Sea-ice growth and water-mass modification in the Mertz Glacier polynya during winter

Andrew Roberts, Ian Allison and Victoria I. Lytle: Sensible and latent heat flux estimates over the Mertz Glacier polynya from in-flight measurements

S. F. Ackley, C. A. Geiger, J. C. King, E. C. Hunke and J. Comiso: The Ronne polynya of 1997/98: observations of air-iceocean interaction

E. C. Hunke and S. F. Ackley: Numerical modeling of the Ronne polynya: an air-ice-ocean interaction event

$1050-1250 h$

CHAIR: Ian Allison

\section{Session 2: Surface Heat Budget of the ARGtic OCEAN (SHEBA)}

Donald K. Perovich, Jacqueline A. Richter-Menge and Walter B. Tucker, III: Seasonal changes in sea-ice morphology

Jackie Richter-Menge, Don Perovich and Scott Pegau: The impact of summer ice dynamics on the surface heat budget of the Arctic Ocean

Mark A. Tschudi, James A. Maslanik and Judith A. Curry: Airborne passive microwave observations of sea ice during SHEBA

C. M. Halle and R. P. Pinkel: Shear variance and associated heat flux in the upper Arctic Ocean during the SHEBA experiment

W. Scott Pegau and Clayton A. Paulson: The albedo of Arctic leads

Mark A. Hopkins: A granular sea ice model of the Arctic ice pack

$1400-1600 h$

CHAIR: Fumihiko Nishio

SESSION 3: REMOTE SENSING OF SEA IGE, I

S. Lyn McNutt and J. E. Overland: Considerations of scale and hierarchy in remote sensing of sea ice in the Beaufort, Chukchi and Bering Seas

Ronald Kwok: Ice deformation, age, and thickness: summary of RGPS results from Nov 96-May 97

Richard R. Forster, David G. Long, Kenneth C. Jezek, Sheldon D. Drobot and Mark R. Anderson: The onset of Arctic sea-ice melt as detected with passive and active microwave remote sensing

S. Gerland, J.-G. Winther, B. V. Ivanov, H. Goodwin and A. Hauser: A ground truth study of sea ice albedo in the Barents Sea during spring and some implications for satellite remote sensing studies

J. J. Yackel and D. G. Barber: On the use of RADARSAT-1 for detection of melt onset over landfast sea ice in the North Water polynya

Sheldon D. Drobot and Mark R. Anderson: Comparison of interannual snow-melt onset dates with atmospheric conditions

$1620-1800 h$

CHAIR: S. Lyn McNutt

\section{Session 4: Remote SENSING OF SEA ICE, II}

Christian Haas: The seasonal cycle of ERS scatterometer signatures over perennial Antarctic sea ice and associated surface ice properties and processes

Benjamin Holt and Seelye Martin: Floe size distribution in the western Arctic: a comparative seasonal analysis

Kazuki Nakamura, Fumihiko Nishio and Hiroyuki Wakabayashi: Study on possibility of sea ice thickness estimation using RADARSATdata

Takeshi Matsuoka, Seiho Uratsuka, Makoto Satake, Tatsuharu Kobayashi, Akitsugu Nadai, Toshihiko Umehara, Hideo Maeno, Hiroyuki Wakabayashi, Kazuki Nakamura and Fumihiko Nishio: CRL/NASDA airborne SAR (Pi-SAR) observations of sea ice in the Sea of Okhotsk

S. Li, X. Zhou, K. Morris, M. Jeffries, D. Hall and G. Riggs: Validation of MODIS derived sea ice cover and ice-surface temperature in the Southern Ocean 


\section{SESSION 5: SEA-ICE DRIFT, DEFORMATION AND THIGKNESS}

Mark R. Drinkwater, Xiang Liu and Sabine Harms: Combined satellite- and ULS-derived sea-ice flux in the Weddell Sea

P. Heil, C.W. Fowler, J. Maslanik, W. J. Emery and I. Allison: A comparison of East Antarctic sea-ice motion derived using drifting buoys and remote sensing

Walter N. Meier and James A. Maslanik: Synoptic-scale ice motion case studies using assimilated motion fields

Matti Leppäranta, Zhanhai Zhang, Jari Haapala and Tapani Stipa: Sea ice kinematics measured with GPS drifters

Bruno Tremblay: The effects of dilatation in large-scale sea ice simulation

W. D. Hibler, III: Modeling the formation and evolution of oriented fractures in sea ice

$1050-1250 h$

CHAIR: Lawson W. Brigham

\section{SESSION 6: POlynyas: ARGTIC}

H. Kassens and I. Dmitrenko: The Laptev Sea and it's climate system: major results of the TRANSDRIFT Expeditions

I. Dmitrenko, J. A. Hoelemann, K. Tyshko, V. Churun and H. Kassens: The Laptev Sea flaw polynya: effects on the mesoscale hydrology

Gregory H. Leonard, Sunny Y. Wu and Antony K. Liu: Satellite observation and model simulation of St. Lawrence Island polynya

D. G. Barber, J. Hanesiak, T. N. Papakyriakou, J. Yackel and C. J. Mundy: The North Water Polynya study: an interdisciplinary, international and interannual research project on Arctic climate change

C. J. Mundy and D. G. Barber: An annual evolution of sea ice cover in the North Water

John Heinrichs, Konrad Steffen and Valerie Sloan: A study of heat transport in Baffin Bay using a coupled ice/ocean data assimilation model

$1050-1250 \mathrm{~h}$

CHAIR: Stephen F. Ackley

\section{SESSION 7: OCEAN WAVES IN SEA ICE}

P. J. Langhorne, V. A. Squire, C. Fox and T. J. Haskell: Lifetime estimation for a fast ice sheet subjected to ocean swell

Vernon A. Squire and Tony W. Dixon: How a region of cracked sea ice affects ice-coupled wave propagation

Hayley H. Shen, Stephen F. Ackley and Mark A. Hopkins: Pancake ice formation in a wave field

Josh Downer, David Tan, Vernon A. Squire and Tony W. Dixon: A granular model of the Antarctic MIZ: sensitivity and application

C. Fox and T. Haskell: Ocean wave speed in the Antarctic MIZ

Tony W. Dixon and Vernon A. Squire: Energy transport in a marginal ice zone

$1400-1600 \mathrm{~h}$

CHAIR: Jean-Louis Tison

\section{Session 8: Palaeo-Sea-Iae Variability and Glimate}

Hezi Gildor and Eli Tziperman: Sea ice, the glacial cycles' climate switch, and inter-hemispheric thermohaline connections

Lloyd H. Burckle: Determining sea ice distribution in the Southern Ocean during the Last Glacial Maximum

Niels Reeh, Henrik Højmark Thomsen, A. K. Higgins and Anker Weidick: Sea ice and the stability of North and North-East Greenland floating glaciers

Fumihiko Nishio, Yoko Toyama, Takayuki Shiraiwa, Tetsuya Fujikawa, Takao Kameda, Yaroslav D. Murav'yev, Alexander A. Ovsyannikov: Interactions between sea ice extents in Okhotsk Sea and Aleutian Low activity derived from Ushkovsky ice cores, Kamchatka

Sharon Jeffers, Tom A. Agnew, Bea Taylor Alt, Roger De Abreu, Roy M. Koerner and Steve McCourt: The effects of the extreme summer of 1998 on the Canadian High Arctic ice regime

Gunter Weller and Patricia Anderson: Impacts of Arctic climate change

Wednesday, 21 June 2000

0830-1030h

CHAIR: Gunter Weller

\section{SESSION 9: VARIABILITY AND GHANGE IN THE ARGTIC: OBSERVATIONS}

Josefino C. Comiso: Satellite observed variability and trend in sea ice extent, surface temperature, albedo, and clouds in the Arctic

John E. Walsh and William L. Chapman: Twentieth-century sea ice variations from observational data

G. V. Alekseev and V. F. Zakharov: Variations of the Arctic sea ice cover during XX century in connection with climate change

P. Wadhams and N. R. Davis: Arctic sea ice morphological characteristics in summer 1996

Y.Yu, D. A. Rothrock and G. A. Maykut: Submarine observations of Arctic sea ice thickness

Jia Wang and Moto Ikeda: Arctic sea ice oscillation: regional and seasonal perspectives 


\section{SESSION 10: VARIABILITy AND GHANGe in THE ARGTIC: Modelling, I}

Larissa Nazarenko, James Hansen, Nickolai Tausnev and Reto Ruedy: Unforced multi-decadal climate variability in a global climate model and equilibrium response to greenhouse forcing

John W. Weatherly and Julie M. Arblaster: Sea ice and climate in 20th and 21st century simulations with a global atmosphereocean-ice model

Cornelia Köberle and Rüdiger Gerdes: Variability in Arctic ice export and volume and some underlying mechanisms

Jari Haapala, Arja Juottonen, Marika Marnela, Matti Leppäranta and Heikki Tuomenvirta: Modelling the variability of the sea ice conditions in the Baltic

Thursday, 22 June 2000

0830-1030h

CHAIR: Christoph Kottmeier

\section{SESSION 11: SEA IGE/ATMOSPHERE/OGEAN: Modelling: ANTARGTIGA}

John Turner, William Connolley, Doug Cressell and Steven Harangozo: The simulation of Antarctic sea ice in the Hadley Centre Climate Model (HadCM3)

Thierry Fichefet, Benoit Tartinville and Hugues Goosse: Sensitivity of the Antarctic sea ice to the thermal conductivity of snow

Xingren Wu, W. F. Budd, A. P. Worby and Ian Allison: Sensitivity of the Antarctic sea-ice distribution to oceanic heat flux in a coupled atmosphere- ${ }^{-}$sea-ice model

Yuxia Zhang and AlbertJ. Semtner: The Antarctic circumpolar wave in a global, high-resolution, coupled ice--ocean model

Jinro Ukita and Douglas G. Martinson: An efficient adjustable-layering thermodynamic sea-ice model formulation for highfrequency forcing

Ted Maksym and Martin O. Jeffries: Phase and compositional evolution of the flooded layer during snow ice formation on Antarctic sea ice

$1050-1250 h$

CHAIR: Gerhard Dieckmann

\section{SESSION 12: HEAT AND FLUID FLOW IN SEA ICE}

H. J. Trodahl, M. McGuinness, P. J. Langhorne and I. J. Smith: Heat flow processes in first year sea ice

J. Freitag and H. Eicken: The hydraulic permeability of Arctic sea-ice from experiments and modelling

K. M. Golden: Brine percolation and the transport properties of sea ice

Manfred A. Lange, Ulrich Buschmann and Bettina Pfleiderer: Oil and sea ice: NMR tomography

P. E. Bond: Modelling the propagation of light in sea ice

J.-L. Tison and M. Jeffries: Gas properties of winter Antarctic pack ice, Ross Sea

$1050-1250 \mathrm{~h}$

CHAIR: Jouko Launiainen

\section{SESSION 13: IGE/OGEAN INTERAGTIONS}

Michael P. Meredith, K. J. Heywood, P. F. Dennis, L. E. Goldson and R. M. P. White: On the variability of the fluxes of sea ice and river runoff from the Arctic to the Greenland Sea

S. Pfirman, H. Eicken, R. Colony, P. Schlosser, I. Rigor, M. Jeffries, D. Bauch, R. Mortlock and G. Boenisch: Drifting Arctic sea ice records changing surface ocean conditions

Inga J. Smith, Patricia J. Langhorne, Tim G. Haskell, H. Joe Trodahl, Russell Frew and M. Ross Vennell: Platelet ice and the land-fast sea ice of McMurdo Sound, Antarctica

M. A. Morales Maqueda: A modelling study on frazil ice formation and sea ice-ocean interactions in coastal polynyas

Leif Toudal and Max D. Coon: Interannual variability of the sea ice induced salt flux in the Greenland Sea

Jörg Haarpaintner, Jane O’Dwyer, Jean-Claude Gascard, Peter M. Haugan, Ursula Schauer and Svein Østerhus: Seasonal water masses, circulation and brine formation observed in Storfjorden

Michael L. VanWoert, Walter N. Meier, Cheng-Zhi Zou, Andy Archer, Andrea Pellegrini, Paolo Grigioni and Cheryl Bertoia: Satellite observations of upper-ocean currents in Terra Nova Bay, Antarctica

1400-1600h

CHAIR: Elizabeth Clare Hunke

\section{Session 14: VARiability and Ghange in the ArGtic: Modelling, II}

W. Maslowski, D. C. Marble, W. Walczowski and A. J. Semtner: On large scale shifts in the Arctic Ocean and sea ice conditions during 1979-1998

Andrey Proshutinsky, Mark Johnson and Tatiana Proshutinsky: Understanding climatic controls on contaminant transport with sea ice in the Arctic Ocean

H. Goosse, F. M. Selten, R. J. Haarsma and J. D. Opsteegh: Decadal variability in high northern latitudes as simulated by an intermediate-complexity climate model

Mark A. Johnson and Igor V. Polyakov: Interannual variability of the Arctic Ocean in 1946-97

A. P. Makshtas: Parameterizations and feedbacks in sea ice models

Michael Hilmer and Thomas Jung: On the link between the North Atlantic Oscillation and Arctic sea ice 


\section{SESSION 15: SEA-ICE ECOLOGY AND BIO/GEOGHEMISTRY}

Peter Wilson, David Ainley, Nadav Nur, Stan Jacobs, Kerry Barton, Grant Ballard and Joey Comiso: Adèlie penguin population growth in the South Pacific sector of Antarctica: relation to sea-ice extent and the Southern Oscillation

H. Goodwin, A. Hauser, A. E. Derocher and M. Mauritzen: Using remote sensing to describe polar bear-sea ice relationships

Sven Günther and Gerhard S. Dieckmann: Vertical zonation and community transition of sea ice diatoms in fast ice and platelet layer, Weddell Sea, Antarctica

Christian H. Fritsen, Susan L. Coale, Diann R. Neenan, Angela H. Gibson and David L. Garrison: Biomass, production and microhabitat characteristics near the freeboard of ice floes in the Ross Sea during the Austral summer

David N. Thomas, Gerhard Kattner, Ralph Engbrodt, Virginia Giannelli, Hilary Kennedy, Christian Haas and Gerhard S. Dieckmann: Dissolved organic matter in Antarctic sea ice

M. A. Granskog and J.Virkanen: Observations on sea ice and surface water geochemistry: implications for importance of sea ice in geochemical cycles in the northern Baltic Sea?

Iris Werner and Rolf Gradinger: Under-ice amphipods in the Greenland Sea and Fram Strait (Arctic): seasonal patterns

$1110-1250 h$

CHAIR: Donald K. Perovich

\section{SESSION 16: SURFAGE ENERGY BUDGET}

Xuanji Wang and Jeffrey R. Key: Spatial variability of the sea ice radiation budget and its effect on aggregate-area fluxes Gerd Wendler and Anthony Worby: The surface energy budget in the Antarctic summer sea-ice pack

Melanie Fitzpatrick, Richard E. Brandt and Stephen G. Warren: Determining the effects of clouds and sea ice on the solar radiation budget in the Southern Ocean from surface measurements

Jouko Launiainen, Cheng Bin, Juha Uotila and Timo Vihma: Turbulent surface fluxes and air-ice coupling in BALTEX-BASIS

B. Brümmer, D. Schröder and S. Thiemann: Energy balance over broken sea ice (measurement and parameterization)

$1400-1600 \mathrm{~h}$

CHAIR: Jacqueline A. Richter-Menge

\section{SESSION 17: SNOW ON SEA IGE}

RobertJ. Oglesby and Susan Marshall: Snowcover over sea ice: improving climate model representation of snow hydrology

Martin O. Jeffries, H. Roy Krouse, Barbara Hurst-Cushing and Ted Maksym: Snow ice accretion and snow cover depletion on Antarctic first-year sea ice floes

V. I. Lytle and S. F. Ackley: Snow ice growth: a fresh water flux inhibiting deep convection in the Weddell Sea, Antarctica

Matthew Sturm, Jon Holmgren and Don Perovich: Snow-ice interface temperature measurements from SHEBA: implications for winter heat flux

J. L. Schramm, J. A. Curry, M. Sturm and D. K. Perovich: Sensitivity of surface and snow/ice interface temperatures to thermal conductivity in a slab snow model

\section{POSTERS}

\section{REMote SENSING OF SEA IGE}

A. Darovskikh, H. Eicken, I. Dmitrenko, J. Groves and U. Blahak: Texture and signature of radar images as indicators of brackish and freshwater ice

Richard J. Hall and Peter Wadhams: Automatic video analysis of sea ice for satellite image interpretation

Nick E. Hughes andRichard Hall: IceCam: an environmental monitoring solution for the polar seas with implications for navigation and safety

W. B. Tucker, III, D. K. Perovich, T. G. Grenfell and B. Light: Using aerial photography to determine Arctic sea ice surface conditions during summer

M. J. Paget, A. P. Worby and K. J. Michael: Determining the floe size distribution of East Antarctic pack ice from digital aerial photographs

Masashige Nakayama, Kohei Cho, Haruhisa Shimoda, Fumihiko Nishio and Tomonori Tanikawa: Evaluation of frequency bands and polarization for sea ice observation using airborne microwave radiometer in the Okhotsk Sea

Hiroyuki Wakabayashi, Takeshi Matsuoka, Kazuki Nakamura and Fumihiko Nishio: Estimation of sea ice parameters using polarimetric SAR: results from Okhotsk and Lake Saroma campaign

Jörg Haarpaintner, Peter M. Haugan and Jean-Claude Gascard: Interannual variability of the Storfjorden ice cover and ice production observed by ERS-2 SAR

Harry Stern, Ron Lindsay, Yanling Yu and Ron Kwok: Validation of RADARSAT geophysical processor system products

Axel Bochert: Interpretation of aircraft-based passive microwave measurements by means of line scanner images

Stefan Kern and Georg Heygster: Sea ice retrieval in the Antarctic based on the SSM/I 85.5 GHz polarization difference

Walter N. Meier, Michael L. Van Woert and Cheryl Bertoia: Evaluation of operational SSM/I ice concentration algorithms 


\section{POLYNYAS AND LEADS}

K. Görgen, J. Bareiss, A. Helbig, A. Rinke and K. Dethloff: An observational and modelling analysis of Laptev Sea ice variations during summer

J. Bareiss and H. Eicken: Siberian river runoff and fast-ice retreat in the Laptev and East Siberian Seas: results from a simple thermodynamic river-discharge-sea-ice model

Karoline Frey, Hajo Eicken, Andrei Darovkikh and Igor Dmitrenko: Satellite observations of new ice formation in the Laptev Sea in relation to surface hydrography

B.V. Ivanov, A. S. Zachek, A. M. Bezgreshnov and I. Dmitrenko: Investigation of radiation and heat interaction processes in the "atmosphere-ice-water" system in the Laptev Sea

T. N. Papakyriakou, R. A. De Abreu, J. Heinrichs, C. J. Mundy and D. G. Barber: Progress on regional energy budget studies in the North Water Polynya

John M. Hanesiak, David G. Barber, Tim N. Papakyriakou and Peter J. Minnett: Incident radiation parameterization schemes in the North Water polynya

K. J. Wilson, D. J. King and D. G. Barber: Tracking annual ice dynamics in the North Water polynya (NOW) using RADARSAT-1

Todd Arbetter: Modeling the North Open Water polynya: comparison of an atmosphere-ice model with an ice--ocean model

R. A. Massom, K. L. Hill, V. I. Lytle, A. P. Worby, M. Paget and I. Allison: Effects of regional fast-ice and iceberg distributions on the behaviour of the Mertz Glacier polynya, East Antarctica

V. I. Lytle, A. P. Worby, R. A. Massom, M. Paget, I. Allison, X. Wu and A. Roberts: Ice formation in the Mertz Glacier polynya during winter

Xingren Wu, W. F. Budd and Ian Allison: A GCM study of the impacts of persistent Antarctic polynyas

G. Budillon, D. Flocco, G. Fusco, G. Spezie and E. Zambianchi: Wintertime variability of Terra Nova Bay polynya

A. Hauser and C. Kottmeier: Interactions between the Terra Nova Bay and the Ross Sea polynyas

\section{Sea-IGe Physical Properties}

Stephen J. Jones and Brian Hill: Structure of sea ice in McMurdo Sound, Antartica

T. J. Haskell and P. J. Langhorne: Some properties of refrozen cracks in sea ice

Colin Fox, Tim G. Haskell and Hyuck Chung: Direct measurement of sea-ice characteristic length

A. P. Nagurny and V. G. Korostylev: Bi-spectral estimation of experimental data as applicable to the method of ice thickness determination in the Arctic Basin

J.-L. Tison and V. Verbeke: Chlorinity/salinity distribution patterns in experimental granular sea ice

Johannes Freitag: Fluid motion through sea-ice pore space: a three-dimensional flow simulation based on a lattice Boltzmann formulation

\section{SEA-IGe Motion AND Deformation}

Josh Downer and Timothy G. Haskell: Ice floe kinematics in the Ross Sea marginal ice zone using GPS and accelerometers Hyuck Chung and Colin Fox: Calculation of wave-ice interaction

Mark A. Hopkins and Hayley H. Shen: Simulation of pancake ice dynamics in a wave field

Yunhe Zhao and Antony K. Liu: Analysis of sea ice motion from satellite data

W. D. Hibler, III: On modeling the anisotropic evolution of pack ice thickness characteristics

Nick Kozlenko and Martin Jeffries: Sea ice drift in the eastern Ross Sea, Antarctica

Martin Doble, Max Coon and Oli Peppe: Pancake ice motion in the winter Weddell Sea: experiments aboard Polarstern during April 2000

\section{SEA-IGE/ATMOSPHERE/OCEAN: MODELLING}

Nadja Steiner: Introduction of variable drag coefficients into sea-ice models

Mikko Lensu: Coupling of ridge field evolution with dynamic ice models

Anne E. Armstrong, Lawrence A. Mysak and Louis-Bruno Tremblay: A comparison of modelled sea-ice concentration with observational data from 1958 to 1998

Larissa Nazarenko and Nickolai Tausnev: Modeling of the Beaufort ice-ocean climatology change

Ye. Aksenov and A. C. Coward: The Arctic Ocean circulation as simulated in a very high resolution global ocean model (OCCAM)

Meibing Jin, Jia Wang, François J. Saucier and Moto Ikeda: General circulation and transport in the pan Arctic and North Atlantic Ocean

Uma S. Bhatt and Sirpa Häkkinen: North Pacific sea ice and its associated atmospheric variability in the NGAR CSM

Bin Cheng, Jouko Launiainen, Timo Vihma and Juha Uotila: Modelling sea ice thermodynamics in BALTEX-BASIS

R. Timmermann, A. Beckmann and H. H. Hellmer: The role of sea ice in the fresh water budget of the Weddell Sea

David A. Bailey and Amanda H. Lynch: Heat flux and open boundary conditions in a regional model of the Southern Ocean

Sandra S. Schuster, W. M. Connolley and J. Turner: First results of an implementation of a viscous-plastic sea ice rheology within a coupled atmosphere- ocean general circulation model (AOCGM)

Philippe Gachon and François J. Saucier: Effects of oceanic conditions in the Gulf of St. Lawrence on wintertime atmospheric circulation in the northwest Atlantic region

\section{SEA IGE VARIABILITY AND GLIMATE}

L.W. Brigham and P. Wadhams: Fast ice in the Russian Arctic: observations from historical sea ice charts

Alexander P. Makshtas and Sergey V. Sutilin: Long-time variability of the Arctic sea ice 
Michael Hilmer: Interannual variability and longterm changes of simulated Arctic sea ice

Christian Haas and Hajo Eicken: Interannual variability of summer sea ice thickness in the Siberian and central Arctic under different atmospheric circulation regimes

Zalman M. Gudkovich and S.M. Kovalev: On some mechanisms of cyclic climate changes in the Arctic and the Antarctic

Hiroyuki Enomoto, Kazutaka Tateyama and Sylviane Surdyk: Winter warming in the higher latitudes and impact on sea ice change

Sohey Nihashi and Kay I. Ohshima: Relationship between the distribution of sea ice in the retreat and advance seasons in the Antarctic Ocean

Raymond C. Smith and Sharon E. Stammerjohn: Variations of surface air temperature and sea ice extent in the western Antarctic Peninsula (WAP) region

Kazutaka Tateyama and Hiroyuki Enomoto: Observation of sea ice thickness fluctuation in the seasonal ice covered area during 1991-1999

\section{SEA-IGE EGOLOGY AND BIO/GEOGHEMISTRY}

D. N. Thomas, H. A. Kennedy, G. Kattner and G. S. Dieckmann: Export of organic matter sedimenting from platelet ice underlying Antarctic fast ice

K. Tuschling, K. Meiners and J. He: Phytoplankton characteristics near the Laptev Sea polynya (Russian Arctic) in spring 1999

Lars Henrik Smedsrud: Experiments with frazil and sediment aggregation

A. P. Stierle, H. Eicken, C. Krembs and K. Junge: Characterization of sedimentary particles and salt precipitates in coastal sea ice from Barrow, Alaska

Christopher Krembs, K. Junge, J. Deming and H. Eicken: First observations on concentration and potential production and fate of organic polymers in winter sea ice from the Chukchi Sea

Virginia Giannelli, David N. Thomas, Christian Haas, Gerhard Kattner, Hilary Kennedy and Gerhard S. Dieckmann: Behaviour of dissolved organic matter and inorganic nutrients during experimental sea ice formation

Karen Junge, Christopher Krembs, Jody Deming, Aaron Stierle and Hajo Eicken: A microscopic approach to investigate bacteria under in-situ conditions in sea-ice samples

T. Mock, A. L. Belem and G. S. Dieckmann: A semi in situ probe to investigate photosynthesis of ice algae in artificial sea ice

J.-L. Tison, C. Haas and S. Sleewaegen: Tank study of physico-chemical controls on gas content and composition during growth of young sea ice

\section{SNOW ON SEA ICE}

J. Iacozza and D. G. Barber: Progress in modelling and measurement of snow distribution and magnitude over first-year sea ice

Mark R. Anderson and Sheldon Drobot: Intra-annual variability in snow melt onset over Arctic sea ice

Hendrik Huwald, Heinz Blatter and Louis-Bruno Tremblay: Impact of a snow layer on the thermodynamics of sea ice

Kim Morris and Martin O. Jeffries: Seasonal contrasts in snow cover characteristics on Ross Sea ice floes

Donald K. Perovich and Bruce C. Elder: The annual temperature cycle of Arctic sea ice

\section{SEA-IGe Optical Properties AND ENERgy BALANGe}

A. Alam, J. A. Curry and M. A. Tschudi: A parameterization of the lead-width distribution and surface turbulent heat flux for sea ice

Richard E. Brandt, Stephen G. Warren and Collin S. Roesler: Spectral albedo, absorptance, and transmittance of Antarctic sea ice

Xiaobing Zhou, Shusun Li and Kim Morris: Measurement of all-wave and spectral albedos of snow-covered summer sea ice in the Ross Sea

M. J. McGuinness, K. A. Landman, H. J. Trodahl and A. E. Pantoja: Solar radiative heating in first year sea ice

Alberto Blanco Sequeiros: Optical properties of sea ice in the northern Baltic Sea

B.V. Ivanov, S. Gerland, J.-G. Winther and H. Goodwin: Energy exchange processes in the marginal ice zone of Barents Sea during spring 1999

Takenobu Toyota and Masaaki Wakatsuchi: Characteristics of heat budget during the ice growing season in the southern Okhotsk Sea from in-situ observations

R.W. Lindsay: Arctic sea-ice albedo derived from RGPS-based ice-thickness estimates

\section{SEA-IGe Growth Properties}

Jinro Ukita, Sharon Stammerjohn, Timothy Newberger and Ray Smith: Early winter sea ice development in the western Antarctic Peninsula region

Noriyuki Tanaka, Toshiyuki Kawamura,Mariko Seimiya and Jinro Ukita: Stable isotopic fractionation during sea ice formation: ice type dependence

Yoko Toyama, Fumihiko Nishio and Junko Hasegawa: Salinity profile and crystallographic anisotropy of sea ice derived from ECM method

K. P. Tyshko, S. M. Kovalev, I. A. Dmitrenko, J. Hoelemann, H. Eicken and H. Kassens: Sea-ice crystal alignment in the southern Laptev Sea

T. Kawamura, K. Shirasawa, N. Ishikawa, A. Lindfors, K. Rasmus, M. Granskog, J. Ehn, M. Leppäranta, T. Martma and R. Vaikmäe: Time series observations of the structure and properties of brackish ice in the Gulf of Finland

Kang Jiancheng, Sun Bo, Sun Junyin, Men Guanglin and Kumiko Goto-Azuma: The characteristics of summer sea ice and their relationship with climate at the Chuckchi Sea, the Arctic Ocean 


\section{SEA-IGE THICKNESS}

Christian Haas and Peter Jochmann: Engineering applications of EM ice thickness measurements

H. Eicken, W. B. Tucker, III and D. K. Perovich: Indirect measurements of the mass balance of summer Arctic sea ice with an electromagnetic induction technique

A. P.Worby, G. M. Bush and I. Allison: A comparison of ice thickness distribution data from upward looking sonar and ship data Sharon Stammerjohn, Jinro Ukita, Ray Smith and Michael Colee: Early winter snow and sea ice thickness in the western Antarctic Peninsula region

Tina Tin and Martin O. Jeffries: Sea ice thickness and roughness in the Ross Sea, Antarctica 